\title{
IMPACT OF POLDER FLOOD PLAIN OF THE CISOWSKA STRUGA ON THE TRANSFORMATION OF FLOOD WAVES BETWEEN GDYNIA AND RUMIA
}

\author{
Michał Szydłowski, Wojciech Szpakowski \\ Faculty of Civil and Environmental Engineering, Gdańsk University of Technology, Gabriela Narutowicza 11/12, 80-233 Gdańsk
}

\begin{abstract}
Aim of the study

The paper presents the results of hydraulic calculations (numerical simulations), which were conducted in order to investigate the role of floodplain (polder) adjacent to the left bank of Cisowska Struga in Gdynia downstream of Hutnicza street in the process of retention and transformation of flood waves occurring in this river due to heavy rainfall.

The paper also addresses the issue of the impact of potential changes in the development of the retention area under consideration for the flood risk in Rumia.

Material and methods

In order to perform hydraulic calculations, mathematical modelling was used. All hydraulic calculations of flood wave transformation in channels and floodplains were performed using the HEC-RAS software and the data on characteristic flows obtained from the available hydrological calculations.

\section{Results and conclusions}

In the light of the obtained results, it should be stated that the analysed retention area between Hutnicza street in Gdynia and the railway line is of high hydrological significance. Potential reduction of the retention capacity of this area will negatively affect the transformation process of flood waves in the Cisowska Struga on the analysed section. At the outlet section in the area of Dębogórska street and further in Rumia, the water level will be elevated, and flood waves will reach there faster. Due to the potential increase of the flood risk in Rumia, this is undesirable.
\end{abstract}

Keywords: mathematical modelling, flood wave transformation, retention, flood risk, Gdynia, Rumia, Cisowska Struga (stream)

\section{INTRODUCTION}

Urbanization and the threat of flooding in the city
Urbanization (from Latin urbanus) is a social and cul-
tural process expressed in the development of cities,
increasing their number, expanding urban areas and
increased share of urban population in the entire pop-
ulace. In Poland as well as throughout the world, this process is continuous, and it is constantly intensifying, sometimes leading to uncontrolled spread of built-up areas (the so-called urban sprawl) (Gutry-Korycka, 2005). The most important hydrological consequences of urbanisation processes include:

- regulation of natural watercourses in urban areas along with compensatory, technical measures for flood protection of the city;

@e-mail: mszyd@pg.edu.pl 
- modification of catchment characteristics in the form of changes to land cover and land development.

Compared to typical catchments (agricultural and forest areas), the urban catchment is characterized by lower natural ability to retain water resulting from the reduction of rainwater infiltration into the ground, reduced evapotranspiration, and the levelling or liquidation of local depressions landforms. As a consequence, the culmination of the runoff from the basin is larger and it occurs faster than in a natural basin. Reducing the retention and shortening the time of runoff culmination from the urbanized catchment is also affected by the rainwater drainage system, which significantly accelerates the process of water runoff. It is acknowledged that the increase in the urbanization level of the catchment shortens the reaction time between precipitation and runoff, and it increases flood runoff in the receiver (Fletcher et al., 2013; Szydłowski, 2007; Wojciechowska et al., 2017). Investment activity in floodplain areas of watercourses and water reservoirs on which cities are located and the modification of hydrological processes in urbanized catchments are the main reasons for the increased threat of flash floods in cities. This threat is also due to the apparent lack of integration of rainwater management and the spatial planning process in these areas (Kowalczak, 2017). The reason for the difficulties should be seen in the boundaries of the areas of the local development plans being defined regardless of the boundaries of catchments of watercourses that receive the rainwater. We should also point out the divergence between the objectives of spatial management focused on the economic aspect, and the objectives of limiting the risk of flooding from rainwater (Januchta-Szostak, 2017). This type of conflict is also visible in the Tri-City area, where we constantly meet with disputes and discussions about the possibilities of transforming natural areas into urbanized areas, and ways of implementing forced rainwater management therein.

\section{Urban floods in the Tri-City area}

The Tri-City is located on the hypsometrically varied areas adjacent to the Gulf of Gdańsk. Terrain elevation changes here, from values below sea level in Żuławy Gdańskie (Gdańsk Marshlands), to al- most $200 \mathrm{~m}$ above sea level in the area of postglacial moraines, located several kilometres from the shoreline. The cities of Gdańsk, Sopot and Gdynia are located between these zones, where locally on the slopes of moraine hills gradients go up to 40. This characteristic terrain layout of the Tri-City's towns affects the spatial distribution and time course of atmospheric precipitation (Weinerowska-Bords et al., 2012; Weinerowska-Bords, 2015; Mikos-Studnicka and Szydłowski, 2015). For example, according to the data collected via the Gdańsk rainfall monitoring system, the annual precipitation in 1971-2000 ranged from $550 \mathrm{~mm}$ in the Gulf of Gdansk and in Żuławy to over $700 \mathrm{~mm}$ in the city districts located at higher altitudes. This is mainly due to the orographic mechanism of rainfall formation in the region of moraine hill valleys.

Along with the development of the agglomeration on the moraine hills, the rainwater drainage system does not significantly expand in terms of increasing the capacity of the collectors located on the lower terrace, which often causes overloading and flooding of the urban areas located lower down during rapid rainwater runoff. This type of urban floods occurred in Gdańsk in 2001 (Majewski, 2002), and again, despite the increase in reservoir retention capacity, in 2010 and 2016 (Wojciechowska et al., 2017). Floods also occurred in Sopot and in Gdynia, for instance, in 2016 (Szydłowski et al., 2017; Widerski et al., 2017). The increase of the flood hazard in the Tri-City area is also affected by investment developments on the floodplains of rivers and streams on the lower terrace of the agglomeration's cities, which significantly reduces their water retention capacity.

The direct cause for the increase in the flood hazard within the Tri-City area lies in the visible development of climate change, witnessed both in Poland and throughout Europe as the observable trend of the air temperature increase (Sulikowska et al., 2016). They are manifested by heavy rainfall, characterized by very high intensity and short duration, and by an increase in the daily sums of precipitation above $100 \mathrm{~mm}$. At the Gdańsk Rębiechowo meteorological station, the maximum daily rainfall in 2001 was recorded at $\mathrm{H}=128 \mathrm{~mm}$, in 2016 at $\mathrm{H}=140 \mathrm{~mm}$, and in 2017 at $\mathrm{H}=100 \mathrm{~mm}$, whereas earlier (in the previous century) the highest value was recorded at $\mathrm{H}=82 \mathrm{~mm}$ 
in 1982 (Szpakowski and Szydłowski 2018). The increased daily sums of precipitation in recent years are also observed in other regions of the world, for example in Georgia (Egiazarowa et al., 2017) or in France (KERAUNOS, 2016).

\section{DATA MATERIAL AND METHODS}

\section{The subject of the study}

The case study of the research described in the present paper was the boundary section of the Cisowska Struga stream, starting from Hutnicza street in Gdynia up to Dębogórska street in the bordering city of Rumia (see: Fig. 1). The Cisowska Struga catchment is a sub-basin of the Zagórska Struga catchment, which is one of the largest rivers in the Rumia municipality. Cisowska Struga is a borderline watercourse that transports water from the municipality of Gdynia, through the areas of the Kosakowo municipality to Rumia. The total area of the Zagórska Struga catchment, starting from the sources to the estuary in the Kanał Łyski (canal), equals 14853 ha. The length of the river is almost $29 \mathrm{~km}$, and the average longitudinal slope is $5.6 \%$. Locally, in the upper course, the val- ue of bottom slope may even exceed $20 \%$, which in selected sections gives the river a mountainous character. Zagórska Struga flows out of Marchowo lake, located at an altitude of $154 \mathrm{~m}$ above sea level in the Szemud municipality, then it crosses the Kashubian Lake District upland, and continues to the valley surrounded by forests of the Tri-City Landscape Park (TPK), to the alluvial fan forming the city of Rumia and the Łyski Canal, and finally enters the Baltic Sea in the Puck Bay.

The total length of the Cisowska Struga is $12 \mathrm{~km}$. The main tributaries of the river include Potok Demptowski (creek) and Potok Marszewski (creek). The area of the Cisowska Struga catchment takes a form of typical moraines formed by the glacier terminus. Locally, as in the case of Zagórska Struga, the longitudinal slope of the river bottom exceeds the values of $20 \%$. Below the border of the forest forming the Tri-City Landscape Park, the river flows through the relatively flat built-up areas of Gdynia, then it flows into the natural area of the Pradolina Kaszubska (Kashubian Proglacial Valley) located in the Gdynia and Kosakowo municipalities. Up to the border with Rumia, $17 \%$ of the catchment area is urbanized, $7 \%$

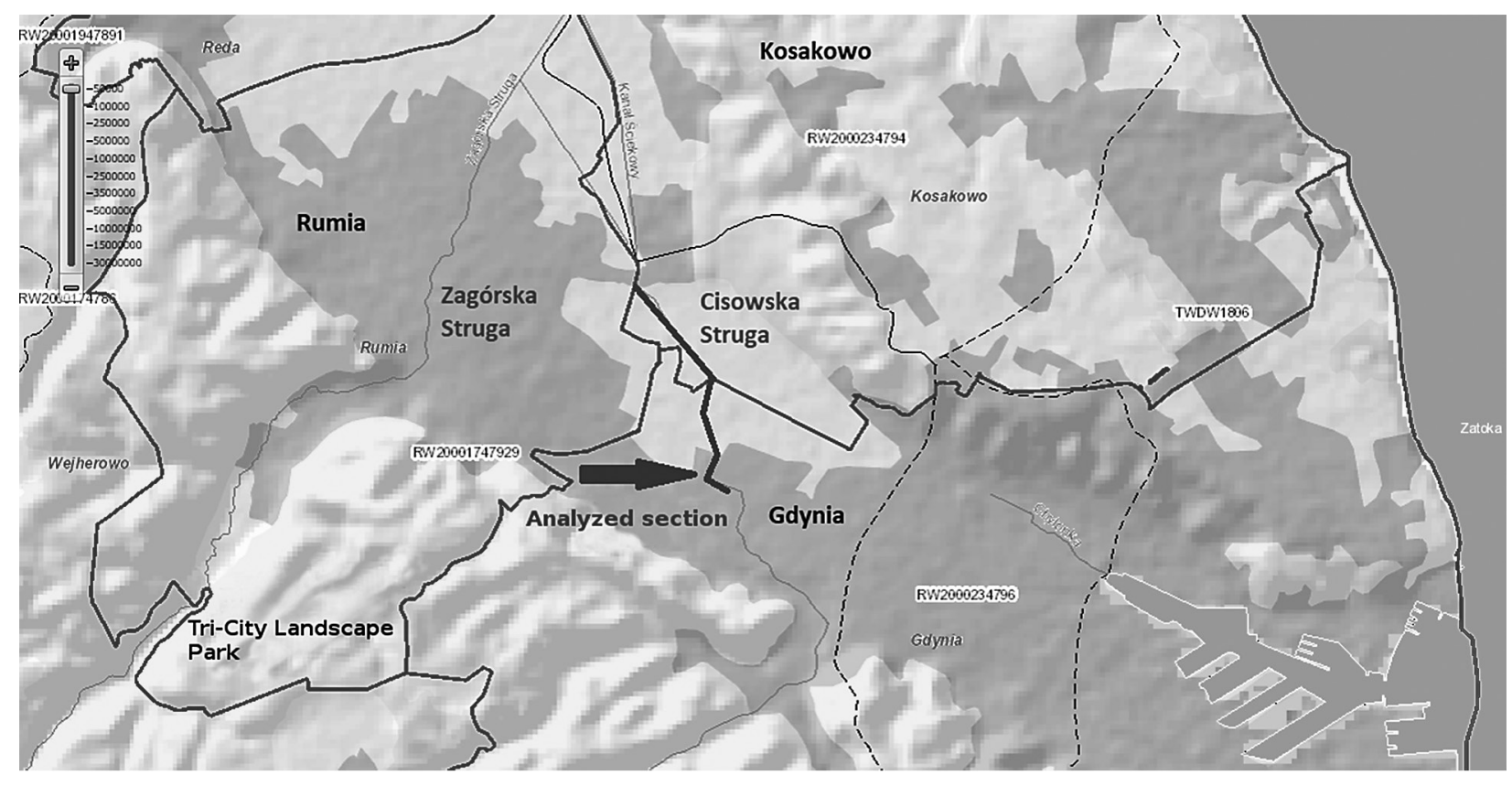

Fig. 1. Sections of Zagórska Struga and Cisowska Struga, against the background of hydrographic and administrative division (own study based on Poland's hydrographic division by PGW Wody Polskie) 
are undeveloped areas, and over $76 \%$ of the area is covered with forest.

Considering the mountainous nature of the upper part of the Cisowska Struga catchment and the dominant urbanization in the central part, it should be noted that the parts of the catchment located in proglacial valley region play crucial role in water retention during floods caused by precipitation. Their largely natural character allows for safe spillage of rainwater flowing from the Gdynia area to floodplains lying within the boundaries of Gdynia and Kosakowo, before they enter the urban area of Rumia. This was also noticed in the "Spatial development plan and spatial development framework for the city of Gdynia" (see: Fig. 2). However, the attractive location of these ar- eas (their proximity to the Port in Gdynia) puts a lot of pressure on transforming fragments of these zones into industrial, which may result in the loss of a part of retention capacity, coupled with an increase in the flood risk.

\section{Spatial location and elevation of the area}

The digital terrain model developed for the city of Gdynia in 2011, with a horizontal grid resolution of 5 by $5 \mathrm{~m}$, was used to perform the flood wave transformation analysis. In turn, the relief (terrain) model was the basic source of information about the objects and the obstacles including road and railway embankments as well as the edges (banks) of the channels and embankments of surface watercourses.
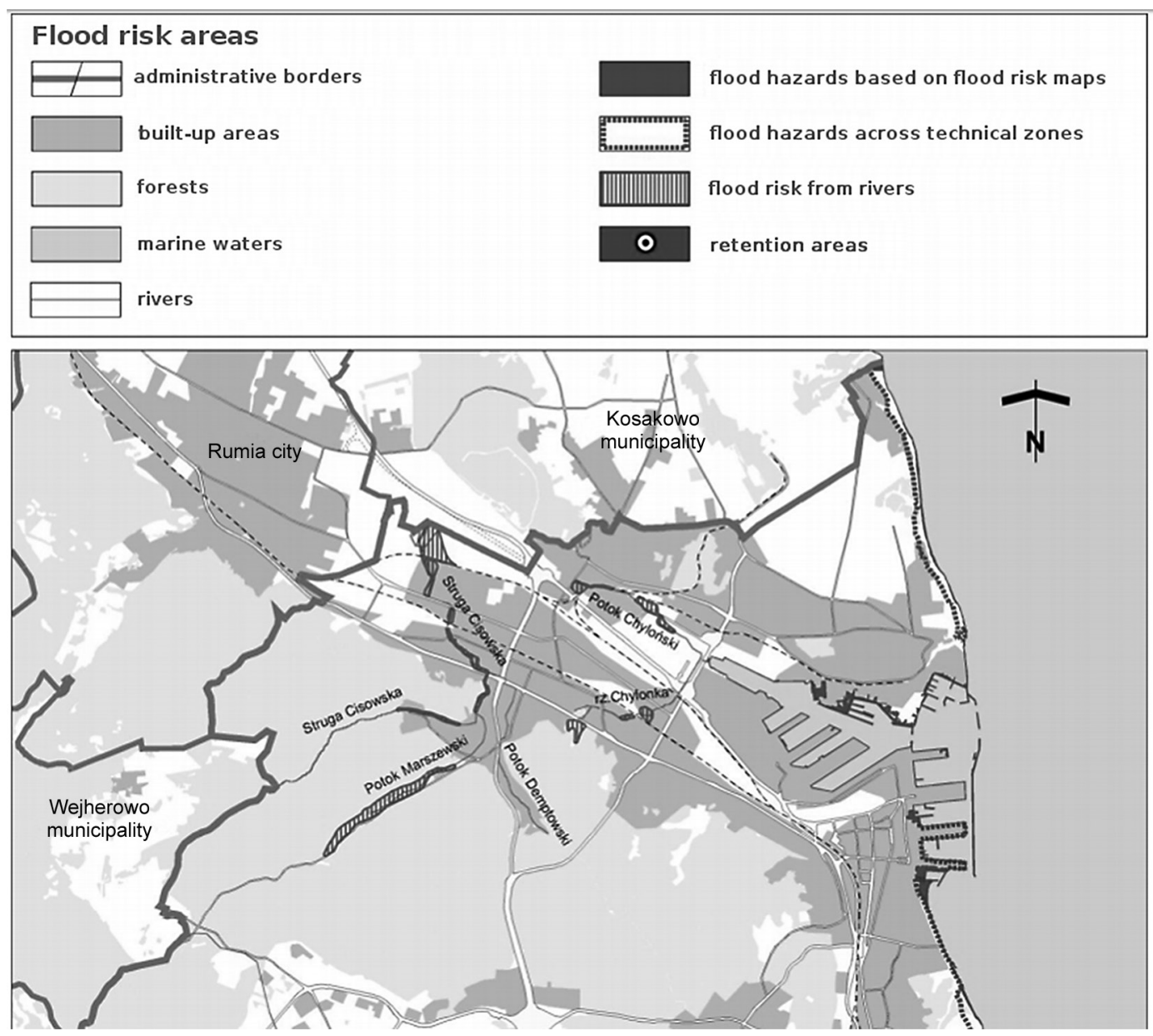

Fig. 2. Part of the map showing flood risk in the Cisowska Struga catchment (marked as shaded areas), based on "Spatial development plan and spatial development framework for the city of Gdynia" 
The location of the flooded area considered in the present work is shown in Fig. 3. The area is located on the left bank of the Cisowska Struga watercourse, and it is bounded by the lines of the banks of this stream and by two embankments - from the south, by a road embankment of Hutnicza street, and from the north, by a railway embankment. It is a drained area, belonging to the Cisowski Rów (ditch) catchment, however, in the present work, its functions during the high-water stage in this ditch had not been analysed; we have only studied its retention function in the situation of high-water stage going through the Cisowska Struga, resulting from the rains with a $10 \%$ and $1 \%$ probability of exceedance. During heavy rains, it is possible for the water to exceed the left crest height of the embankment, and overflow the flood plain, flooding it with the waters of the Cisowska Struga.

The left bank of the Cisowska Struga along the section between Hutnicza street and the railway embankment is slightly elevated, and the stream bed itself is above the studied floodplain. The relied of the floodplain area is shown in Fig. 3. Directly below the
Hutnicza street, the stream flows between two industrial areas on an artificial elevation exceeding $17 \mathrm{~m}$ above sea level, then on the section to the railway embankment, Cisowska Struga enters the open area. There, the left bank of the riverbed, slightly elevated, flows irregularly and follows the ordinates from 15.8 to $16.2 \mathrm{~m}$ above sea level, while the bottom of the stream drops from the ordinate of about 15.6 to $15.1 \mathrm{~m}$ above sea level. The left-bank flood plain is located much lower than the banks and the bottom of the streambed, in its lowest places, drops down to the ordinate of $14.2 \mathrm{~m}$ above sea level. In the present system, waters spilling from the Cisowska Struga riverbed cannot return to the channel on the same section of the watercourse, and they almost entirely have to propagate down the catchment, below the railway line, via two culverts under the railway embankment. These two culverts constitute the basic drainage route, with water accumulating on the analysed flood plain. Under normal conditions, the culverts provide water from the Rów Cisowski ditch and its drainage system, while in special situations they also discharge the water over-
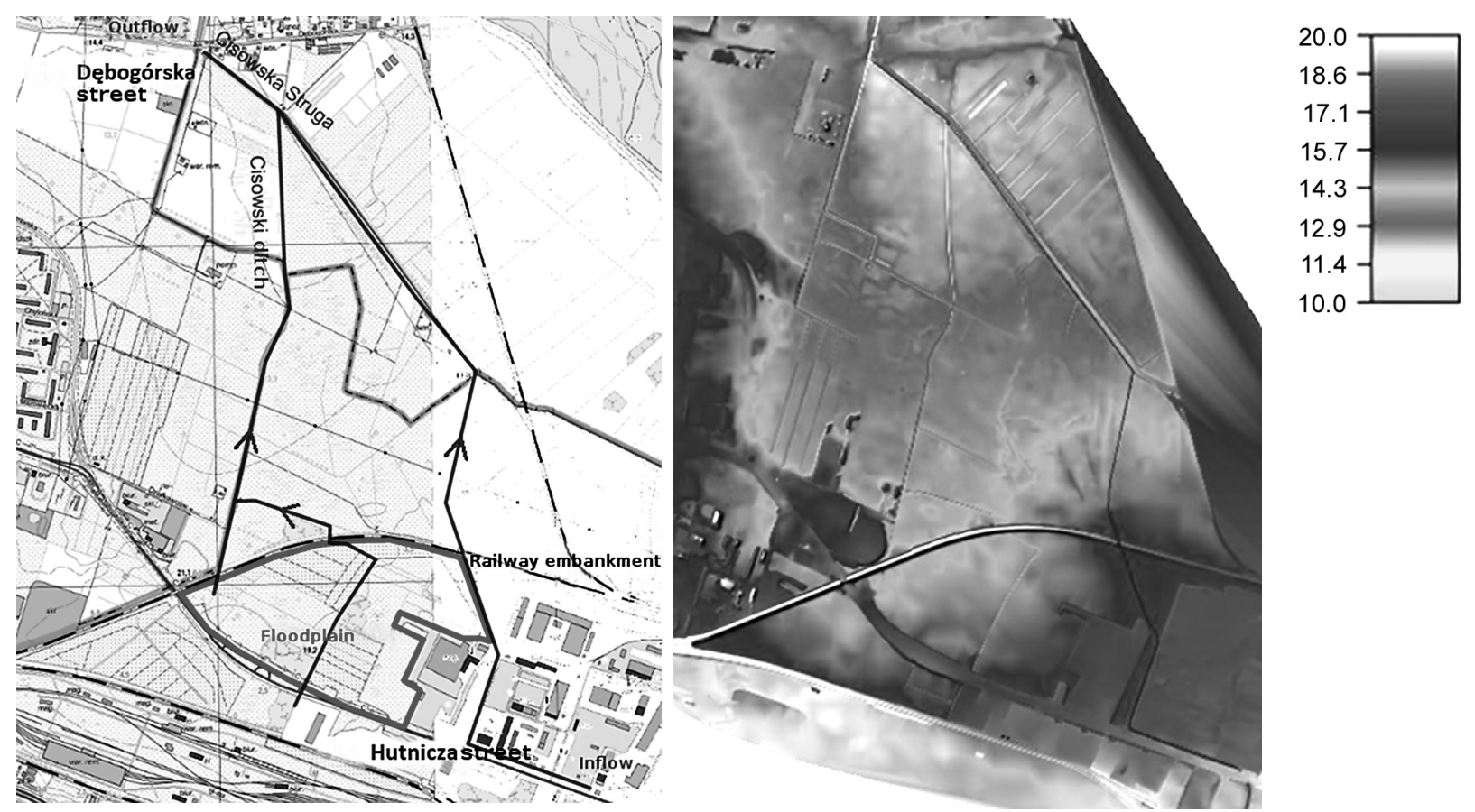

Fig. 3. Location and the terrain (relief) of analysed retention area (based on the 1992 topographic map in the scale of 1:10000. Map not to scale) 
flowing from the Cisowska Struga riverbed. Both culverts have rectangular cross-sections, with the widths of 1.5 and $1.2 \mathrm{~m}$ respectively, and heights of 1.5 and $1.7 \mathrm{~m}$. The railway bridge over the Cisowska Struga is a concrete bridge without pillars with a span of 4 $\mathrm{m}$. The last hydraulic link is the culvert under Hutnicza street. The latter culvert provides the analysed area with the water from the Rów Cisowski catchment located in the vicinity of Morska street. It is a small diameter culvert, and it was not taken into account in the hydraulic calculations.

\section{Options of floodplain modifications}

In the analysis of the flood wave transformation processes on the Cisowska Struga, various options were adopted, taking into account the entire right-bank flood plain as well as the varying size of the available flood plain on the left bank of the watercourse (see: Fig. 4). The option corresponding to the current actual situation was considered, as well as two hypothetical scenarios assuming potential reduction of the left bank retention area as a result of raising the elevations of some parts or the entire area above the expected level of flood waters in Cisowska Struga. In the present situation (option 1), the area of the left-bank flood plain is about $284.300 \mathrm{~m}^{2}$, in option 2 it was arbitrarily reduced to $121660 \mathrm{~m}^{2}$, while in option 3 it was reduced down to zero.

\section{Hydrological data}

Scenarios of hypothetical rainfalls that could potentially occur in the Cisowska Struga channel, with the probability of exceedance $p=1,2,10$, and $100 \%$, were taken from previous hydrological calculations
(Szydłowski and Zima, 2011). To compute flow hydrograms for selected rainfalls with different probabilities of exceedance, the rain duration of $24 \mathrm{~h}$ was assumed with an asymmetrical intensity distribution, with the maximum intensity in the middle of the episode. Using the SCS-CN method, recommended by the Polish Hydrologists Association (Banasik et al. 2017), the effective rainfall hietograms were calculated for each of the analysed sub-catchments, and then - using the triangular unit hydrogram method, also proposed by SCS - the corresponding discharge hydrograms were computed for the closing cross-sections (gauging stations). In this study, two calculated flood waves, corresponding to hypothetical rains with the duration of one day and a probability of exceedance $(p)$ of $10 \%$ and $1 \%$ respectively, were used to analyse flood wave transformation in the Cisowska Struga. For the simulation, flood flow hydrograms were used, calculated for the hydrological cross-section (gauging station) located directly at Hutnicza street. In the case of rain with a probability of $p=10 \%$, the cumulative discharge is $7.2 \mathrm{~m}^{3} \cdot \mathrm{s}^{-1}$, whereas the maximum flow rate value for rain with a probability of $p=1 \%$ is $14.8 \mathrm{~m}^{3} \cdot \mathrm{s}^{-1}$ (see: Fig. 5). The total volume of outflow through the cross-section of the Cisowska Struga directly below Hutnicza Street equals 316 thousand $\mathrm{m}^{3}$ and 688 thousand $\mathrm{m}^{3}$ respectively. The hydrological scenarios presented above were used as the upper boundary condition at the inflow to the analysed section of the channel (see: Fig. 3).

\section{Hydrodynamic model}

In order to perform hydraulic calculations, mathematical modelling was used. The calculations of the flow transformation in the main channel of the Cisowska
Option 1

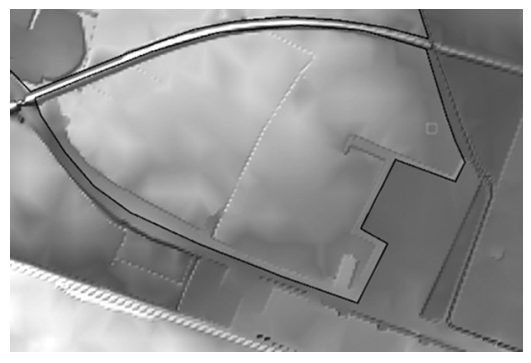

Option 2

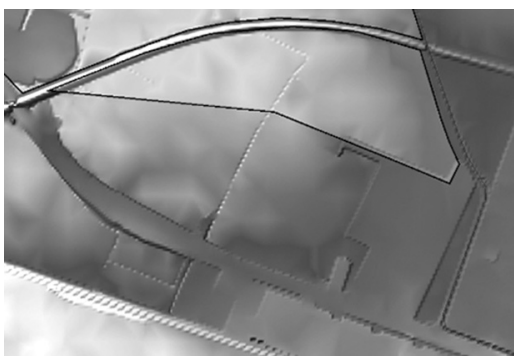

Option 3

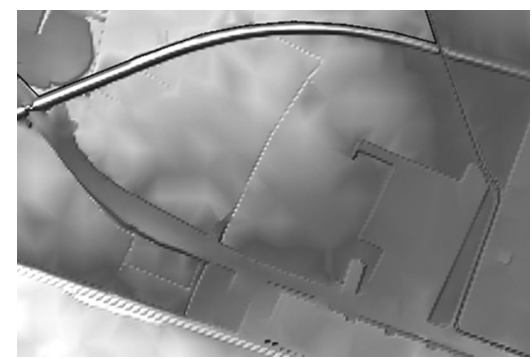

Fig. 4. Options of the available floodplain (the area of possible retention is marked with a transparent layer) 


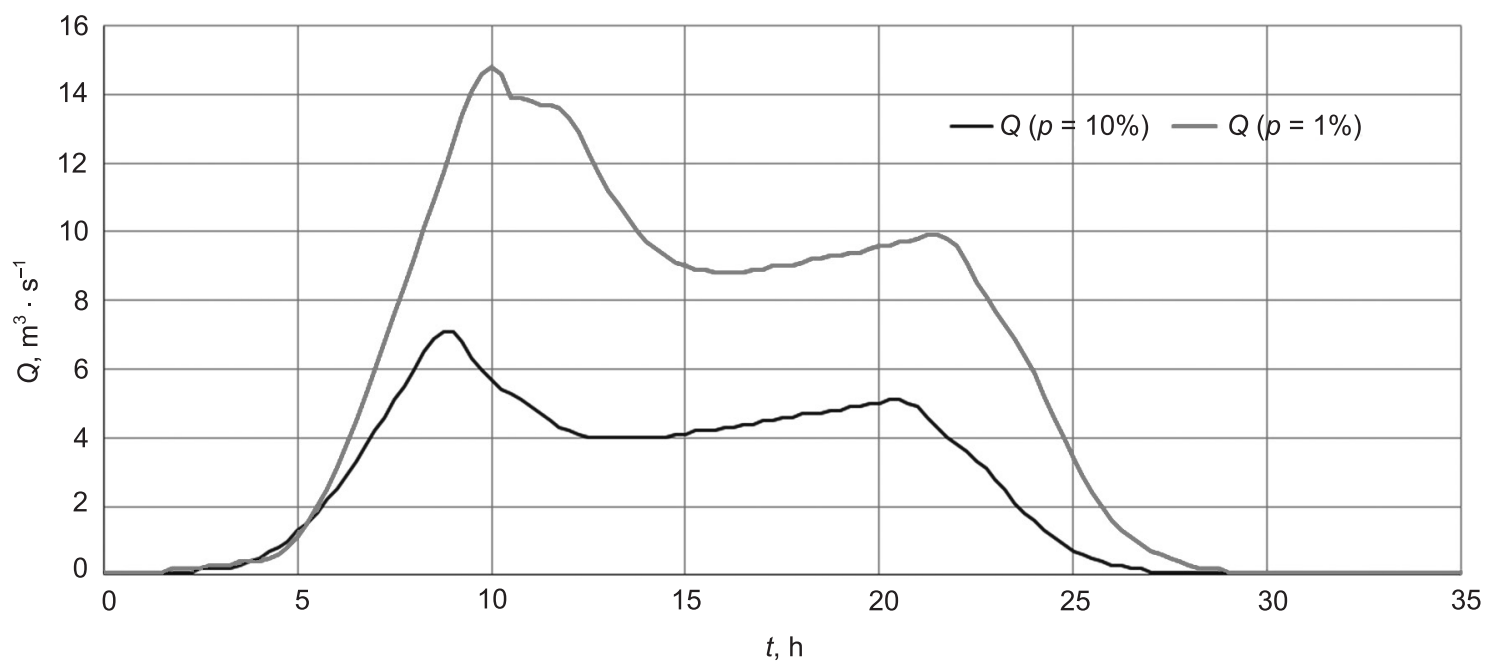

Fig. 5. Hydrograms of hypothetical flood waves

Struga were made using the one-dimensional module of the HEC-RAS model (Brunner, 2010), assuming the conditions of unsteady flow. The HEC-RAS model is used for mapping both steady and unsteady flow, and it is often applied in engineering analyses of complex hydrographic systems (Kałuża et al., 2017), including flow through polder-type retention areas (Sosnowska, 2016). In the calculation of the one-dimensional gradually varied unsteady flow over time, the model uses de Saint-Venant equation (Szydłowski, 2007):

$$
\begin{gathered}
\frac{\delta h}{\delta t}+\frac{\delta(u h)}{\delta x}=0 \\
\frac{\delta u}{\delta t}+u \frac{\delta u}{\delta x}-g\left(S_{o}-S_{f}\right)=0
\end{gathered}
$$

In these equations, symbol $x$ represents spatial variable, $t$ represents time, $g$ - gravitational acceleration, $h$-water depth, $u$ - averaged velocity in the cross-section of the channel, and $S_{o}$ and $S_{f},-$ the channel bottom slope, and energy grade lines slope, respectively. The solution of the system of equations $(1,2)$ for the given initial-boundary conditions is obtained through the functions $u(x, t)$, and $h(x, t)$. On their basis, the values of the flow rate function $Q(x, t)$ are calculated.

However, in order to correctly represent the complex water flow structure on flat flood plains, at least two-dimensional flat horizontal water flow should be simulated. In the presented work, simulations of flows on left-bank flood plains, above and below the railway line, were made using the two-dimensional flow module of the HEC-RAS model, assuming - as previously - unsteady flow conditions. Shallow water equations are the adopted model of two-dimensional, horizontal free-surface flow, used in the program (Szydłowski, 2007). The basic assumption during the derivation of model equations is the gradually varied water movement. It is also assumed that the vertical component of the velocity is negligible, resulting in a lack of vertical accelerations, whereas the pressure distribution is hydrostatic and the bottom slope gradients are not significant. In the two-dimensional case, after omitting the dissipation of the momentum, which is the result of the turbulence, as well as the dispersion of the momentum, which is the effect of velocity averaging, the form of the unsteady water flow equations is as follows:

$$
\frac{\delta h}{\delta t}+\frac{\delta(u h)}{\delta x}+\frac{\delta(v h)}{\delta y}=0
$$

$$
\frac{\delta(u h)}{\delta t}+\frac{\delta\left(u^{2} h\right)}{\delta x}+g h \frac{\delta h}{\delta x}+\frac{\delta(u v h)}{\delta y}-g h\left(S_{o x}-S_{f x}\right)=0
$$

$$
\frac{\delta(v h)}{\delta t}+\frac{\delta\left(v^{2} h\right)}{\delta y}+g h \frac{\delta h}{\delta y}+\frac{\delta(u v h)}{\delta x}-g h\left(S_{o y}-S_{f y}\right)=0
$$


where: $x$ and $y$ symbols represent spatial variables, $t$ represents time, $g$ - gravitational acceleration, $h-$ water depth, $u$ and $v$ are components of the flow velocity vector, averaged along the depth, whereas $S_{o}$ and $S_{f}$ are the channel bottom slope and energy grade lines slope, resepctively. The above system of equations $(3,4,5)$ is a system of partial differential equations of the hyperbolic type, whose solution for given initial-boundary conditions lies in the functions $u(x, y, t)$, $v(x, y, t)$ and $h(x, y, t)$. In some cases, when it is possible to omit the inertial force in the equation of motion, the above model is simplified to the so-called diffusion wave model, and such simplification was used in the analysis. Furthermore, the flow modelling takes into account the existing hydrotechnical structures in riv- erbeds, that is the embankments of channels with the possibility of water overflowing. Also accounted for were the connections between different zones of oneand two-dimensional flow, such as the culverts under the embankments, which is one of the available options within the HEC-RAS system.

\section{CALCULATIONS AND DISCUSSION OF RESULTS}

\section{Numerical simulations}

In the first step, using the HEC-RAS program, a numerical grid and a hydraulic connections system were developed for individual components of the entire system. An example of such a scheme, developed for option 1, is shown in Fig. 6. It consists of the river mod-

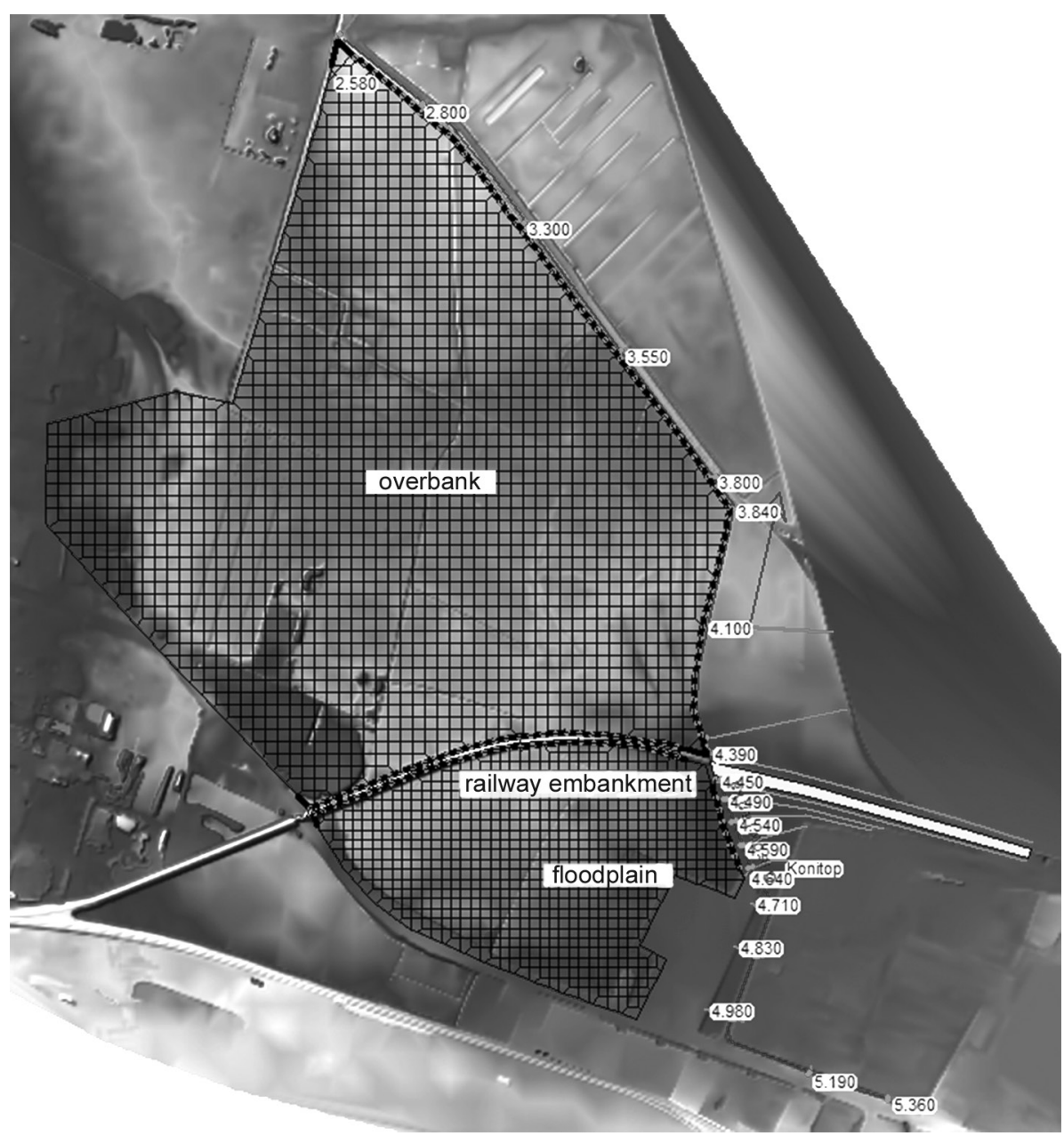

Fig. 6. Numerical mesh of the flow area in option 1 
el, built from individual cross-sections of the channel and the right-bank part of the valley, described with a mileage, and two flood plains covering the areas along the left bank of the watercourse, paced upstream and downstream the railway embankment, respectively. The inlet to the system takes place via a cross-section located at $\mathrm{km} 5+360$ and the outlet is at $\mathrm{km} 2+$ 580. Hydrotechnical facilities that have been mapped in the model primarily include the embankment of the left bank of the Cisowa Struga, as well as the railway embankment with the bridge and the culverts.

Within the analysis of flood wave transformation, calculations of surface flow were made for three assumed options of the floodplain geometry (see: Fig. 4) and for two hydrological scenarios (see: Fig. 5). In all cases, the duration of the modelled flows was 2 days, assuming a rainfall lasting 24 hours.

\section{Flood extent delineation}

First, comparison was made between the maximum ranges and depths of floods corresponding to three available flood plain options as well as the flood waves resulting from precipitation of $p=10 \%$ and $p=1 \%$, respectively (see: Fig. 7). When analysing the results, we concluded that in the case of a flood wave for the $p=10 \%$ precipitation, the dominant flooding path in the current scenario (option 1), as well as in the scenario where the floodplain is partly reduced (option 2), is the area located along the Rów Cisowski.

Flood waters propagating through the Cisowska Struga channel mostly overflow the left bank on the section upstream the railway line. The main channel, under the railway bridge, provides such amount of water that does not exceed the capacity of the watercourse on the section downstream the said bridge, with no flooding of floodplains along the Cisowska Struga. Most of the water spills over the left bank and is retained in the area between Hutnicza street and the railway embankment, and then gradually outflows through two culverts down to the Rów Cisowski ditch. The amount of water flowing into the ditch exceeds its maximum capacity, causing the flooding of areas adjacent to the ditch, below the railway embankment. Afterwards, flood waters pass down Rów Cisowski to Cisowska Struga, and then outflow finds outlet in this watercourse through the section in Dębogórska street towards Zagórska Struga. A part of surface water remains in the flood plains in the form of surface retention, which will later evaporate or infiltrate into the ground. This is unlike option 3 , in which the analysed area is completely excluded from the retention function, for instance by its backfilling or introducing a high embankment from the side of the Cisowska Struga river bed. In such hydraulic system, all floodwaters must flow through the main channel of the Cisowska Struga under the railway bridge, which causes the overflowing of water from the banks on the section downstream the railway bridge, and leads to the flooding of areas adjacent to the watercourse. When comparing the results obtained for precipitation $p=10 \%$ (see: Fig. 7), we notice how the flooding path from areas adjacent to the Rów Cisowski changes when the flood plain below Hutnicza street is used for retention; and flow is redirected to the areas along the Cisowska Struga channel when the area is completely excluded from the water retention function.

When analysing the results of the maximum flood extent obtained for the hypothetical flood wave from precipitation $p=1 \%$, it should be noted that increased flows can be expected already in option 2 - assuming exclusion from retention of more than half of the analysed area - and these increased flows are expected both in the Rów Cisowski and the Cisowska Struga, rather than either one or the other watercourse, as before. As a result, in option 2, flooding of the floodplains below the railway line along both streams can be observed. As a consequence of such course of flooding, larger parts of the area located below the railway embankment would be covered with water.

\section{Maximum flow rates and elevations of the water table}

In order to assess the role of the floodplain located between Hutnicza street and the railway embankment in the process of flood wave transformation in Cisowska Struga, apart from changes in the flooding route, some other hydraulic parameters have been analysed, such as maximum values of discharges (flow rates) and water levels in the closing cross-section (at $\mathrm{km} 2+$ 580 of the analysed watercourse). The results, shown in Table 1, confirm that in the case of a flood wave caused by the hypothetical rain of $p=10 \%$ probability, the impact of changes in the floodplain area between Hutnicza street and the railway embankment (options 1 and 2) on the maximum outflow parameters is not 
Szydłowski, M., Szpakowski, W. (2019). Impact of polder flood plain of the Cisowska Struga on the transformation of flood waves between Gdynia and Rumia.Acta Sci. Pol., Formatio Circumiectus, 18(1),113-126. DOI: http://dx.doi.org/10.15576/ASP.FC/2019.18.1.113

Option $1, p=10 \%$

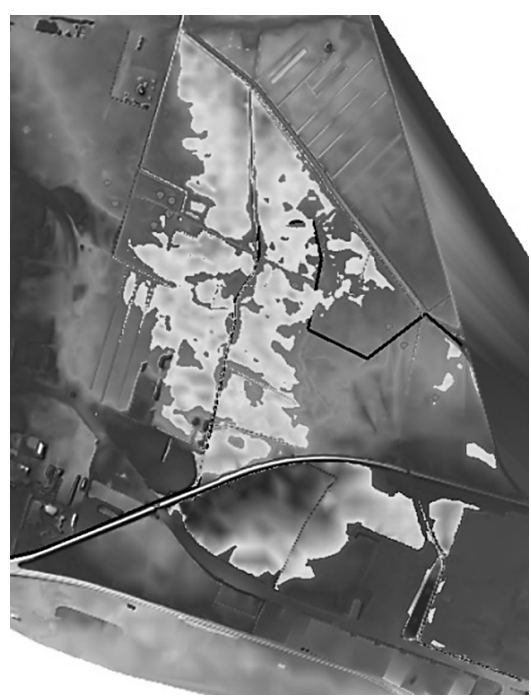

Option $1, p=1 \%$

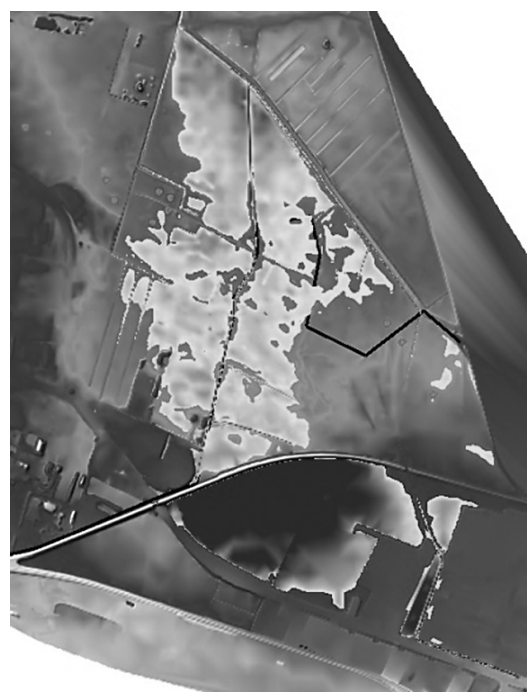

Option $2, p=10 \%$

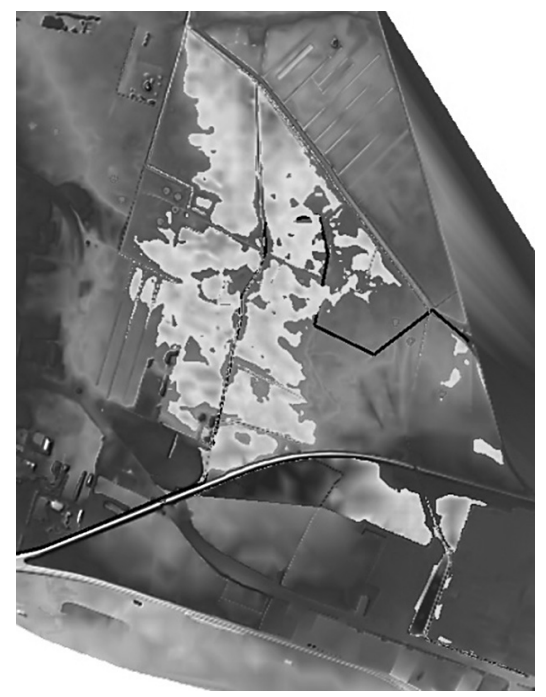

Option $2, p=1 \%$

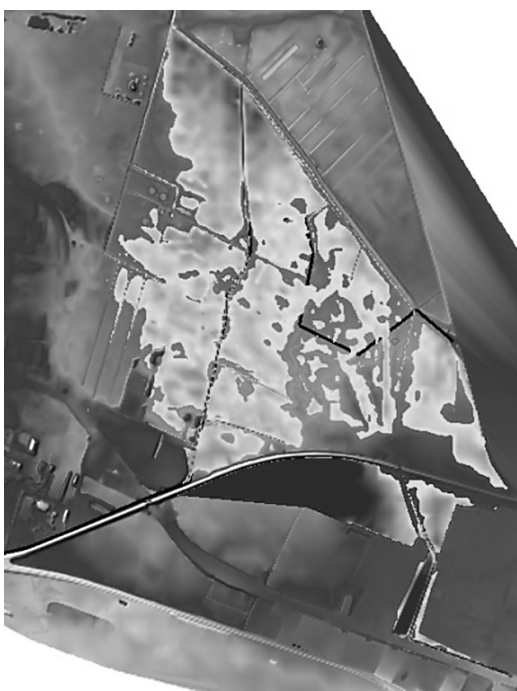

Option 3,p $=10 \%$

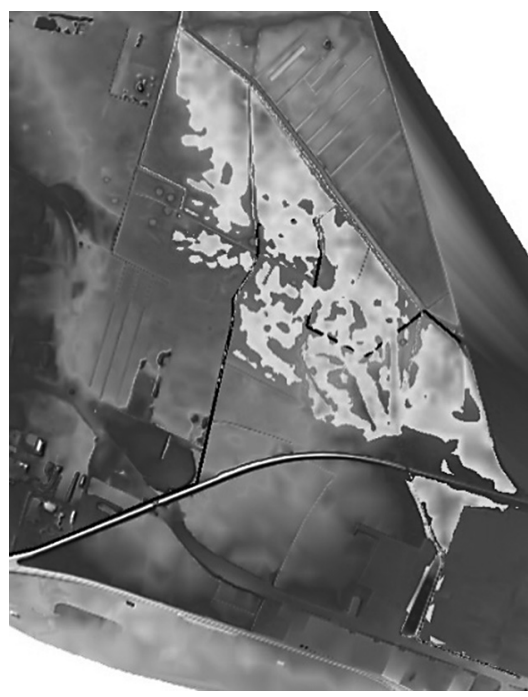

Option $3, p=1 \%$

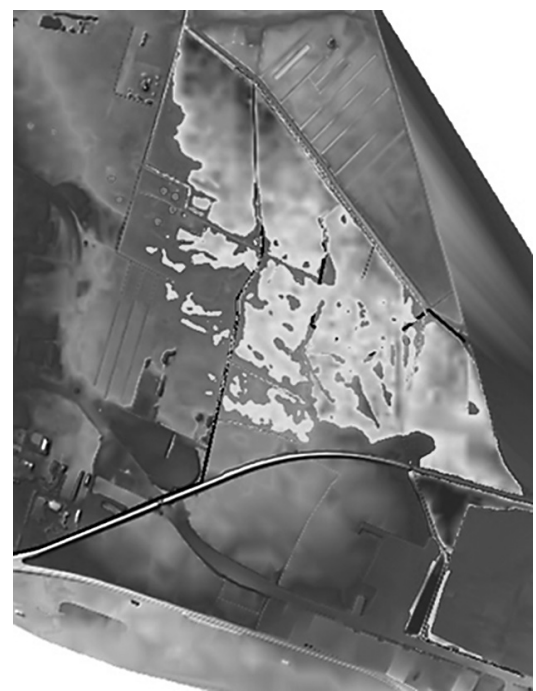

Fig. 7. Maximum flood extent (the darkest color of the flood zone corresponds to a depth exceeding $1 \mathrm{~m}$ )

Table 1. Parameters of flood waves at the outlet section (Dębogórska street in Rumia at km 2+580)

\begin{tabular}{ccccccc}
\hline Option & $\begin{array}{c}\text { Flow rate } \\
{\left[\mathrm{m}^{3} \cdot \mathrm{s}^{-1}\right]} \\
(\mathrm{p}=10 \%)\end{array}$ & Increase $[\%]$ & $\begin{array}{c}\text { Water level } \\
{[\mathrm{m} \text { a.s.1.] }} \\
(\mathrm{p}=10 \%)\end{array}$ & $\begin{array}{c}\text { Flow rate } \\
{\left[\mathrm{m}^{3} \cdot \mathrm{s}^{-1}\right]} \\
(\mathrm{p}=1 \%)\end{array}$ & $\begin{array}{c}\text { Water level } \\
{[\mathrm{m} \text { a.s.1.] }} \\
(\mathrm{p}=1 \%)\end{array}$ \\
\hline 1 & 4.55 & - & 11.63 & 7.44 & - & $1 \% .00$ \\
\hline 2 & 4.60 & 1.1 & 11.64 & 8.23 & 10.6 & 12.10 \\
\hline 3 & 5.06 & 11.2 & 11.70 & 9.95 & 33.7 & 12.31 \\
\hline
\end{tabular}


very significant (increase in the maximum flow value around $1 \%$ ). Their value is primarily influenced by the capacity of the railway culverts, through which the flood waters flow to the Rów Cisowski and further to Cisowska Struga. Only complete shutdown of the analysed retention area (option 3), and directing all waters to the Cisowska Struga channel under the railway bridge causes a visible increase in the flow culmination $(11 \%)$ and hence an increase in the maximum water level elevation to $11.7 \mathrm{~m}$ above sea level. This means that all the water in this cross-section is contained within the main channel, as long as the bankfull stage remains at ca. $12 \mathrm{~m}$ above sea level.

The situation changes when we analyse the transformation of the flood wave caused by hypothetical precipitation of $p=1 \%$. With such a potential flood event, it is apparent that the impact of reducing retention in the area between Hutnicza street and the railway embankment is of significant importance for the cross-section in Dębogórska street in Rumia. The flow culmination values in options 2 and 3 increase by more than $10 \%$ and $30 \%$ respectively, compared to option 1 .
In addition, in options 2 and 3, as a result of diverting more water into the Cisowska Struga riverbed under the railway bridge, the levels of the water table clearly increase in option 3 , and they exceed the value of water edge, reaching an elevation of over $12.3 \mathrm{~m}$ above sea level. In this region, such values of the water level ordinates will cause the flooding of water onto the left bank of the Cisowa Struga, which may pose a threat of flooding the areas below Dębogórska street.

\section{Flood waves propagation time}

An important factor characterizing the process of flood waves transformation is their propagation within the hydrographic systems. As a rule, slower flow of flood water through a given catchment results in a lower culmination of flow in downstream parts of the catchment and the closing cross-section. Among other things, this is due to the quick outflow from the lower parts of the basin, which do not interfere nor cumulate with flood waves coming from upper areas.

When analysing the diagrams of flood hydrographs on the Cisowska Struga presented in Fig. 8, we ob-

Outflow waves, $p=10 \%$

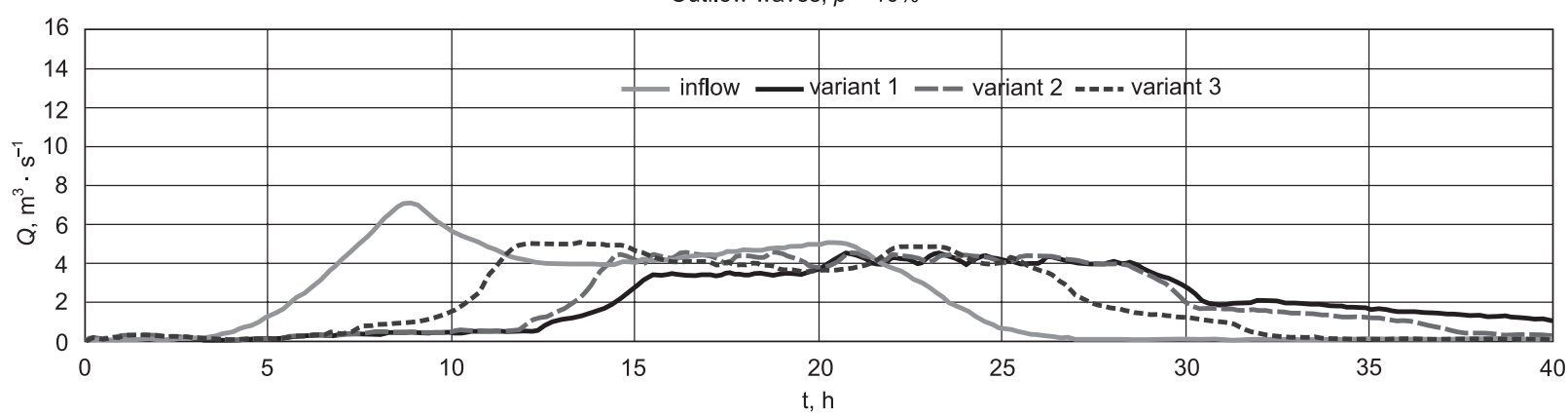

Outflow waves, $p=10 \%$

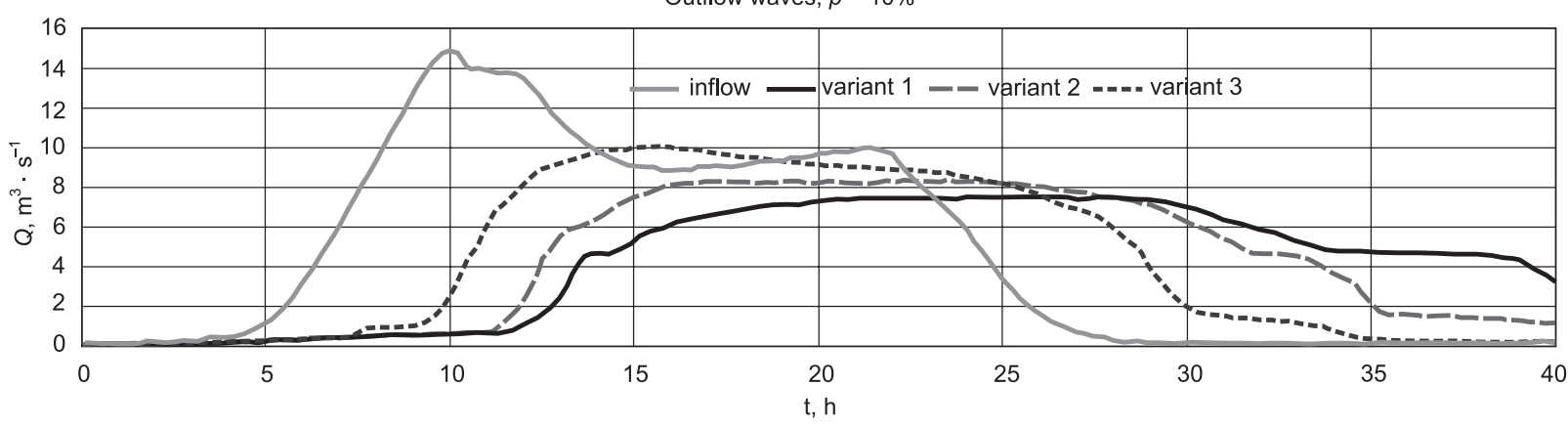

Fig. 8. Flow hydrograms at the inlet section (Hutnicza street in Gdynia) and at the outlet section (Dębogórska street in Rumia) 
serve that while for two different probabilities of occurrence of a precipitation episode, the diagrams differ as to the flow rate in the watercourse, the time distributions (velocities) of the waves remain similar. In both hydrological scenarios, in the inlet cross-section to the analysed area $(\mathrm{km} 5+360)$, the beginning of the flood wave takes place after about 3 hours from the beginning of the rainfall. The maximum discharge for $p=10 \%$ occurs after 9 hours of rainfall, and the maximum wave for $p=1 \%$ occurs 10 hours into the phenomenon. In the case of a flood wave transformation in the current state of floodplains (option 1), the wave reaches the outlet section at Dębogórska street in Rumia, 12 hours after the beginning of the precipitation. Potential reduction of retention in subsequent parts of the floodplain area located between Hutnicza street and the railway embankment (options 2 and 3) would result in shortening the time of the flood wave arrival at the outlet section. In both hydrological scenarios $(p=10 \%$ and $p=1 \%)$, in option 2 , the time of the flood wave reaching the outlet cross-section is shorter than in option 1 by about 1 hour, and in option 3 , by 5 hours.

\section{SUMMARY AND CONCLUSIONS}

The main purpose of the present study was to examine the role of the flood plain adjacent to the left bank of the Cisowska Struga downstream Hutnicza street in Gdynia in the process of water retention and the transformation of flood waves occurring in this watercourse. The calculations we have performed, including different variants of flood flow simulations made it possible to formulate the following conclusions, summarizing the research we conducted.

- The flood plain analysed in the study plays an important role in the flood wave retention process at Cisowska Struga. Although, formally, it is located in the Rów Cisowski catchment above the railway embankment, in the current situation it is through this area that most of the flood waters from Cisowska Struga flow on the cross-border section between Gdynia, Kosakowo and Rumia. This happens after flood waters have spilled over through the left bank of the channel above the railway embankment. The process of possible reduction in the surface of the considered retention area significantly changes the route of the flood surge, increasing the flood hazard in the areas adjacent to the Cisowska Struga

- The examined options of gradually decreasing retention area between Hutnicza street and the railway embankment from the retention function affect the change of flood wave parameters at the outflow from the analysed part of the Cisowska Struga catchment. The reduced size, and thus the smaller retention capacity of the analysed area, causes elevation of the water table and the maximum flow as well as simultaneous acceleration of the flood waters run-off in the Cisowska Struga. Such changes may lead to a significant increase of the flood hazard to areas downstream the closing cross-section, that is, in Rumia below Dębogórska street.

Considering the presented results of the analyses as a general example and the state of knowledge on the changes in hydrological processes observed in recent years, manifested primarily by the increase in the frequency and amount of heavy rainfall, it should be noted that the strategic action of local authorities in cities threatened by flash floods should strive to preserve all existing areas of natural rainwater retention. In addition, it is important to enforce administrative restrictions regarding the sealing of catchment areas, as well as a continuous search for the possibility of creating small-scale retention systems including household retention. Moreover, it is absolutely necessary that all activities related to spatial planning in such cities adopt a catchment approach as a tool to increase the chance of preventing urban floods.

\section{REFERENCES}

Banasik, K., Wałęga, A., Węglarczyk, S., Więzik, B. (2017). Aktualizacja metodyki obliczania przepływów i opadów maksymalnych o określonym prawdopodobieństwie przewyższenia dla zlewni kontrolowanych i niekontrolowanych oraz identyfikacji modeli transformacji opadu w odpływ. Warszawa: Stowarzyszenie Hydrologów Polskich. Brunner, G.W. (2010). HEC-RAS, River Analysis System Hydraulic Reference Manual. Computer Documentation Report, Report no. CPD-69, US Army Corps of Engineers, Hydrologic Engineering Center (HEC).

Fletcher, T.D., Andrieu, H., Hamel, P. (2013). Understanding, management and modelling of urban hydrology 
and its consequences for receiving waters: A state of the art, Advances in Water Resources, 51, 261-279.

Gutry-Korycka, M. (ed.) (2005). Urban SPRAWL - Warsaw Agglomeration case study, Warszawa: Wydawnictwo Uniwersytetu Warszawskiego.

Januchta-Szostak, A. (2017). Podejście zlewniowe w urbanistyce jako narzędzie zapobiegania powodziom miejskim, Przegląd budowlany, 9, 30-33.

Kałuża, T., Jasiak, A., Krysztofiak, B., Zaborowski, S. (2017). Ocena warunków funkcjonowania węzła wodnego nowy młyn w kontekście konieczności zachowania ciągłości ekosystemu rzeki Wełny. Acta Sci. Pol., Formatio Circumiectus, 16(4), 233-242.

KERAUNOS French observatory storms and tornadoes, (2016). An extraordinary storm on the Cote d'Azur on October 3, 2015, at. Keraunos.org 2016.

Kowalczak, P. (2017). Planowanie przestrzenne a powodzie miejskie, Przegląd budowlany, 9, 25-29.

Majewski, W. (2002). Powódź w Gdańsku w lipcu 2001, Gospodarka Wodna, 1.

Mikos-Studnicka, P., Szydłowski, M. (2015). Wpływ jakości danych hydrologicznych na oszacowanie odpływu ze zlewni miejskiej na przykładzie Potoku Strzyża w Gdańsku, Inżynieria Ekologiczna, 44, 139-153.

Sosnowska, A. (2016). Możliwości polderyzacji obszaru zawala w rejonie Stężycy nad Wisłą. Acta. Sci. Pol., Formatio Circumiectus, 15(4), 309-319.

Szpakowski, W., Szydłowski, M. (2018). Opady prawdopodobne w Gdańsku w świetle zmian klimatycznych, Acta Sci. Pol. Formatio Circumiectus, 17(3), 175-183.
Szydłowski, M. (2007). Modelowanie fal powodziowych na terenach zabudowanych, Gdańsk:Wydawnictwo Politechniki Gdańskiej.

Szydłowski, M., Zima, P. (2011). Koncepcja odwodnienia obszaru Gdyni położonego w zlewni Strugi Cisowskiej, obejmującej ten ciek i jego dopływy: Potok Marszewski, Potok Demptowski i Rów Cisowski, II Część hydrologiczna dla stanu istniejącego, Hydroprojekt Gdańsk.

Szydłowski, M., Szpakowski, W., Widerski, T. (2017). Analiza wezbrania rzeki Kaczej w Gdyni po opadzie z 14 lipca 2016 r., Gospodarka Wodna, 6, 161-167.

Weinerowska-Bords, K., Szydłowski, M., Bielecka, K. (2012). Analiza czasowej i przestrzennej zmienności opadów w zlewni Potoku Strzyża w Gdańsku., Inżynieria Morska i Geotechnika, 6, 490-500.

Weinerowska-Bords, K., (2015). Development of Local IDF-formula Using Controlled Random Search Method for Global Optimization, Acta Geophysica 63,1, DOI: 10.2478/s11600-014-0242-5.

Widerski, T., Szydłowski, M., Szpakowski, W. (2017). Measurement and analysis of a flood wave propagation on the Kacza River in Gdynia in Northern Poland, 17th International Multidisciplinary Scientific GeoConference SGEM2017, Water Resources. Forest, Marine and Ocean Ecosystems, 453-460.

Wojciechowska, E., Gajewska, M., Matej-Łukowicz, K. (2017). Wybrane aspekty zrównoważonego gospodarowania wodami opadowymi na terenie zurbanizowanym. Gdańsk: Politechnika Gdańska.

\section{WPŁYW POLDEROWEGO TERENU ZALEWOWEGO CISOWSKIEJ STRUGI NA TRANSFORMACJĘ FAL WEZBRANIOWYCH MIĘDZY GDYNIĄ A RUMIA}

\section{ABSTRAKT}

\section{Cel pracy}

W artykule przedstawiono i przeanalizowano wyniki obliczeń hydraulicznych w procesie retencji wód opadowych i transformacji fal wezbraniowych występujących wskutek nawalnych deszczy. Analizy zostały wykonane na potrzeby zbadania roli terenu zalewowego (polderu), położonego poniżej ulicy Hutniczej, przyległego do lewego brzegu cieku Cisowska Struga w Gdyni.

\section{Materiat i metody}

Wszystkie obliczenia transformacji fal wezbraniowych w korycie cieku i na terenach zalewowych wykonano w systemie symulacji numerycznych HEC-RAS, wykorzystując dane dotyczące przepływów charakterystycznych uzyskane z dostępnych oszacowań hydrologicznych. W obliczeniach połączono dostępną w programie obliczeniowym możliwość modelowania przepływu jednowymiarowego w korycie rzeki i dwuwymiarowego na terenach zalewowych. Podstawowe dane do przeprowadzenia obliczeń jednowymiarowych stanowiły: pomierzone geodezyjne przekroje poprzeczne koryta Cisowskiej Strugi, przekroje przepustów 
kolejowych i drogowych oraz współczynnik oporów przepływu wg Manninga. Podstawą obliczeń dwuwymiarowych był numeryczny model terenu zaczerpnięty z zasobów geodezyjnych miasta Gdyni oraz dane o pokryciu i zagospodarowaniu powierzchni terenu.

\section{Wyniki i wnioski}

Obliczenia transformacji fali wezbraniowej wykonano dla przepływów odpowiadających opadowi o prawdopodobieństwie przekroczenia $10 \%$ i 1\%, wykorzystując hipotetyczny hydrogram odpływu ze zlewni Cisowskiej Strugi. Obliczenia wykonano dla wariantów odpowiadających planowanym w koncepcjach planu zagospodarowania miasta Gdyni zmianom funkcji badanego terenu. Wyniki obliczeń wykazały, że układ przestrzenny badanego obszaru retencyjnego cieku jest istotny hydraulicznie, bowiem znacznie wpływa na proces transformacji fal wezbraniowych na tym odcinku Cisowskiej Strugi. W wyniku zmniejszania terenu zalewowego, stwierdzono między innymi szybsze przemieszczenie się fal wezbraniowych wzdłuż cieku oraz wzrost ich kulminacji i objętości. Między innymi ze względu na potencjalny wzrost zagrożenia powodziowego w Rumi zmniejszanie pojemności retencyjnej tego terenu jest niepożądane.

Słowa kluczowe: modelowanie matematyczne, transformacja fal powodziowych, retencja, zagrożenie powodziowe, Gdynia, Rumia, Cisowska Struga 